Received 14.03.2016 Reviewed 13.04 .2016 Accepted 26.04.2016

A - study design

B - data collection

C - statistical analysis

D - data interpretation

E - manuscript preparation

F - literature search

\section{The role of the gallery in the functioning of the foggara}

\author{
Boualem REMINI ABCDEF
}

University of Blida, Technology Faculty, Department of Water Sciences, Blida 9000, Algeria; e-mail: reminib@yahoo.fr

For citation: Remini B. 2016. The role of the gallery in the functioning of the foggara. Journal of Water and Land Development. No. 29 p. 49-57. DOI: 10.1515/jwld-2016-0011.

\begin{abstract}
In this article, we have highlighted the role of the gallery to improve the flow rate of foggara. The study based on observations and use of the latest inventory data (census 1998). The gallery of foggara can be divided into two parts: drainage and transport. The "drainage" part which is located inside the aquifer occupies $2 / 3$ of the gallery of the foggara. The "transport" part of a length equal to $1 / 3$ of the gallery of the foggara. Knowing the operating principle of the foggara, old methods of improving the flow of foggara were proposed. These included extension of the drainage part of the gallery, strengthening the base of the sealing of the transport part of the gallery, the realization of a small foggara and digging wells downstream of the main foggara.
\end{abstract}

Key words: flow rate, foggara, gallery, Gourara, Touat, water

\section{INTRODUCTION}

The scarcity of the surface water in arid region pushed the man to exploit the groundwater. Various techniques of water catchment have been used for centuries. One technique that has marked the history of hydraulics is the qanat. On the Iranian origin [GOBLOT 1979], the qanat is called foggara in Algeria and the khettara in Morocco [LightFoOT 1996]. Thanks to its success, the foggara has spread to 52 countries worldwide [REMINI et al. 2014a]. In the Algerian Sahara, several foggaras were realized in the Ahaggar [REMINI, ACHOUR 2013a], in the region of In Salah [REMINI, AcHOUR 2013b], in Mzab Valley [REMINI et al. 2012b], in the oasis of Ouled Said [REMINI, ACHOUR 2013c], in the region of Kenadsa [REMINI et al. 2014b] and in the Saoura valley [REZOUG et al. 2016]. In the Touat and Gourara the Algerian Sahara, the foggara has been developed for over 10 centuries [REMINI et al. 2011]. Over 1400 foggaras were dug around the Tadmait tray; which is considered the true water tank qanats of Touat and Gourara. A flow rate of $3 \mathrm{~m}^{3} \cdot \mathrm{s}^{-1}$ in a continuous manner in more than 2,000 km of gallery which has developed approximately 200 palms [ABIDI, REMINI 2011]. Unfortunately for socio economic problems, there has been in recent years to the degradation of these techniques, the number of foggara has decreased to 700 foggaras operating according to the latest inventory carried out by the National Agency of Water Resources in 2011. The contribution of new techniques for capturing the real problem of depletion of foggara. Over $50 \%$ of service foggara saw their reduced rate. The drainante part of the gallery is the real pump foggara whose flow is directly related to its length. It is in this sense that this study attempts to show the role of drainante part on the operation and performance of foggara.

\section{STUDY AREA AND DATA USED}

To explain the role of drainante part of the gallery, we studied the foggaras of regions of Touat and Gourara. The choice of these foggaras is justified by the number and diversity of existing of foggaras in this region, which is considered the country of fogga- 
ras. Four missions in 2007, 2008, 2010, 2011 and 2015 to try to understand the role of the drainage gallery in the functioning of a foggaras. Over 20 foggaras were visited.

Touat and Gourara which contain about 200 palm groves are located more than $1,000 \mathrm{~km}$ south of the capital Algiers (Fig. 1). Over 90\% of Algerian foggaras are located in the Touat and the Gourara which are considered the country of foggaras. All these foggaras capture the waters of the aquifer of Intercallary Continental on the outskirts of Tadmait plate. For the study of relationships, we used the data of foggaras of inventory 1932, 1960, 1998 and 2011. The last two surveys were developed by the National Agency of Water Resources.

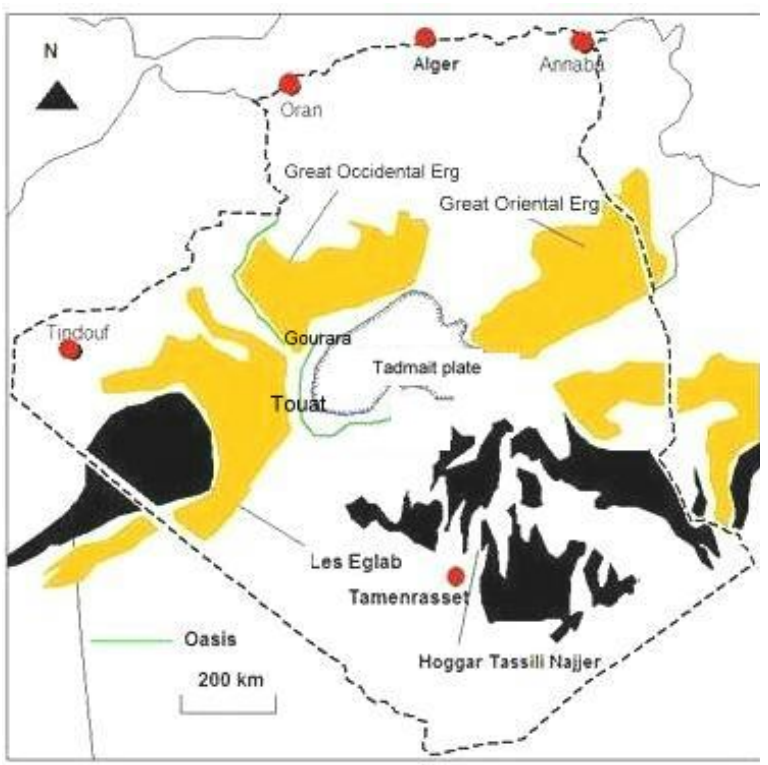

Fig. 1. Location of the study area; source: own elaboration

\section{RESULTS AND DISCUSSION}

\section{FUNCTIONING OF A FOGGARA}

A foggara is an underground gallery equipped with ventilation shaft which consists of draining water from a sheet of water to irrigate land situated below (Fig. 2 and 3). On arrival of water from the ground level, it will be distributed among the owners via a diverter comb of triangular shaped called main Kasria (Fig. 4a). The share of water each family will be channeled through an irrigation channel (channel) (Fig. 4b). Before arriving at Madjen each farmer the water will be distributed again by a lower dimensional Kasria the first Kasria called secondary (Fig. 4c). Then, each flow rate of water flows in a Seguia small dimensions to achieve a tertiary Kasria and so on until Madjen (water tank) (Fig. 4d). Once the water is stored in the basin, it will be used for irrigation of the garden called Guemoun of owner (Fig. 4e). The water flow is according to the contribution of each owner to maintain the foggara.

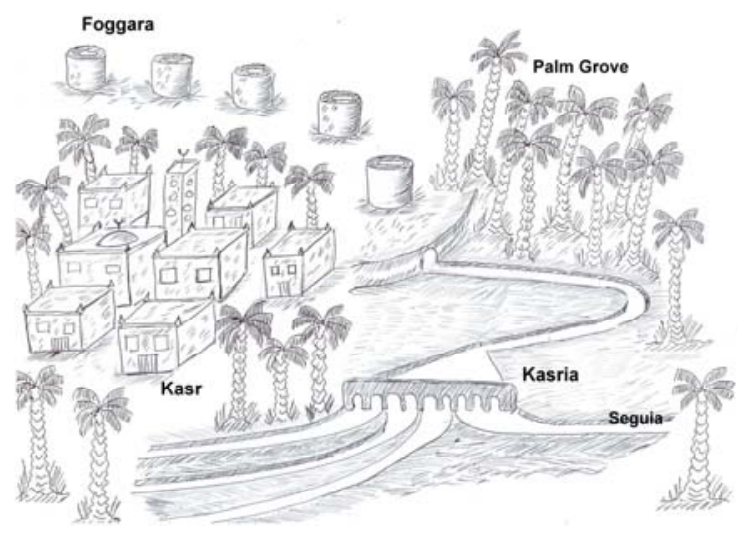

Fig. 2. Simplified diagram of a foggara; source: own elaboration

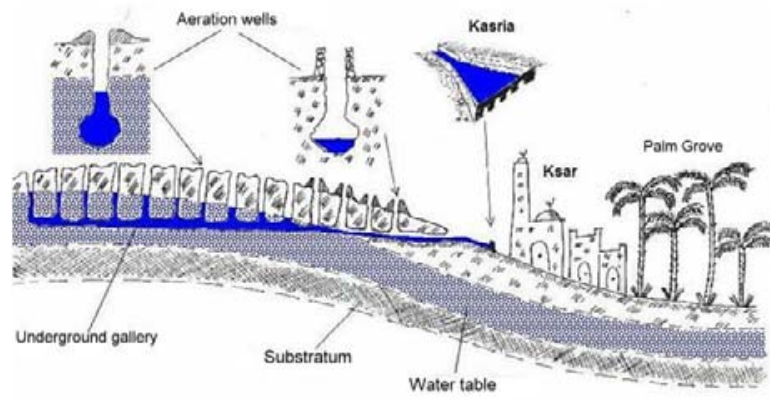

Fig. 3. Longitudinal section of a foggara of Touat; source: own elaboration

To ensure a fair and sharing of water between the owners, the ancestral rules were established by the local population for centuries. Thus, each instrument has its oasis of flow measurement (Chekfa), the unit of measure (called Habba) and the person responsible for making the measurements of flow called Kial El Ma. At each Ksar (the city of farmers), there is a council of elders called Dajmaa that deals with all the problems of the oasis.

\section{CONCEPT OF THE DRAINAGE GALLERY}

The gallery is the main structure with a foggara whose geometric dimensions: length, slope and the wet section affect the discharge of the foggara. In the oases of the Touat and Gourara, the length of the gallery of a foggara varies from thirty meters to 14,000 meters. El Kebira foggara of Ksar Metarfa possesses a gallery of length of $14 \mathrm{~km}$ equipped by 1700 wells. It is located in the oases of Augrout and can be classified as the largest foggara in the Algerian Sahara. Also in the oases of Augrout, the Amradj foggara possessing a $10 \mathrm{~km}$ of gallery ventilated by 2000 wells and can be classified as the first in the Algerian Sahara on the number of wells. On the one gallery with a length of $9 \mathrm{~km}$ and aerated with 380 wells, El Meghier foggara is considered the largest of the oases of Timimoun [REMINI,ACHOUR 2008]. As shown in Table 1 , there is no relationship between the length of 

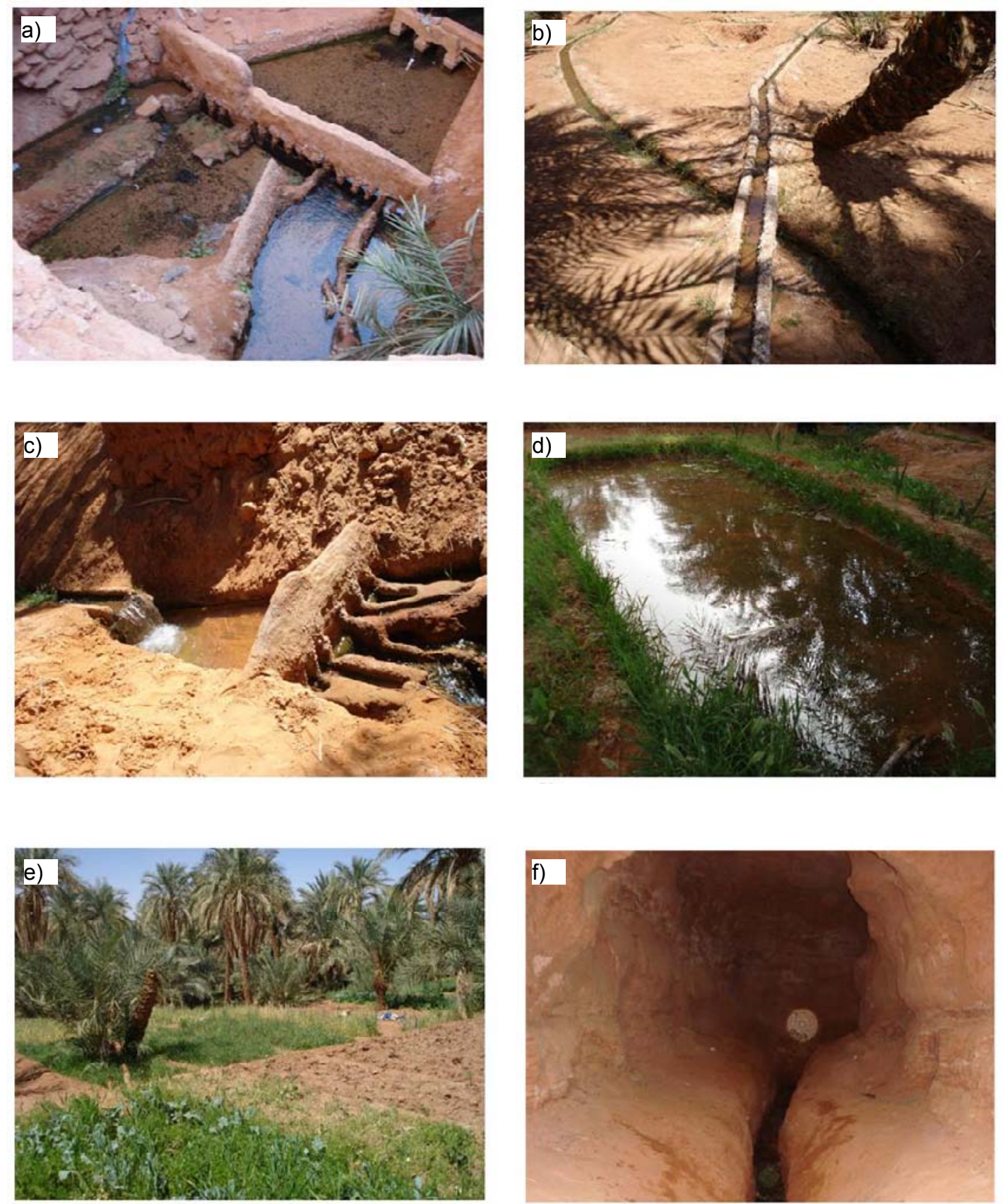

Photo 1. The different parts of a foggaras: a) The main kasria of El Meghaier foggara in the oasis of Timimoun;

b) Seguias of El Meghaier foggara to bring water until Madjen in the oasis of Timimoun; c) Secondary kasria of La Salma foggara in the oasis of Timimoun; d) Madjen (tank) of La Salma foggara in the oasis of Timimoun;

e) Guemoun (garden) in the oasis of Timimoun; f) A section of the non-active part of the gallery of the foggara of La Salma (phot. B. Remini)

Table 1. The foggaras the longest in the Algerian Sahara

\begin{tabular}{|l|l|c|c|c|}
\hline \multicolumn{1}{|c|}{ Oasis } & Foggara & $\begin{array}{c}\text { Length } \\
\text { of the gallery } \\
\mathrm{km}\end{array}$ & $\begin{array}{c}\text { Number } \\
\text { of wells }\end{array}$ & $\begin{array}{c}\text { Spacing } \\
\text { between wells } \\
\mathrm{m}\end{array}$ \\
\hline Aougrout & Amradj & 10 & 2000 & 5 \\
\hline Aougrout & Seghira & 14 & 1200 & 12 \\
\hline Augrout & Kebira & 13 & 1800 & 7 \\
\hline Augrout & El Kebira & 14 & 1700 & 8 \\
\hline Timimoun & El Meghier & 9 & 380 & 23 \\
\hline Adrar & Igrenij & 8 & 1200 & 6 \\
\hline
\end{tabular}

Source: Inventory of National Agency of Water Resources of 1998. the gallery and the number of ventilation shafts. The spacing between two wells varies from $5 \mathrm{~m}$ to $23 \mathrm{~m}$.

Along a gallery of a foggara of the Touat and Gourara there are different profiles sections: circular, rectangular and triangular same. For the same gallery, the dimensions of the sections are never constant (Fig. 4). The shape of the gallery depends on the stability and the nature of the soil. It is very difficult to give an exact value of a gallery dimensions. In a circular, the diameter ranges from $0.8 \mathrm{~m}$ to $1.6 \mathrm{~m}$. For a rectangu- 


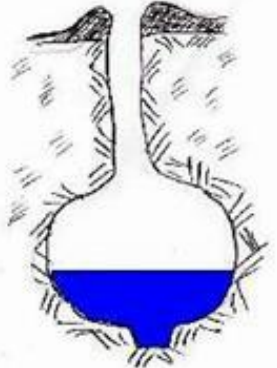

Circular

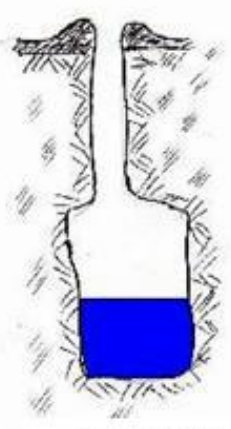

Rectangular

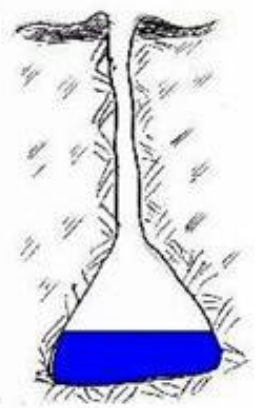

Triangular

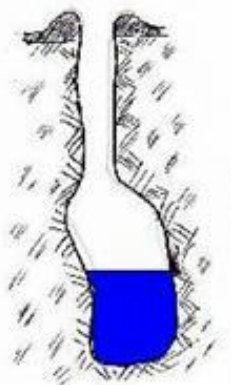

Rounded
Fig. 4. Profiles sections of a gallery of foggara; source: own elaboration

lar section in size from $0.5 \mathrm{~m}$ to $1.5 \mathrm{~m}$ wide and $1 \mathrm{~m}$ to $2 \mathrm{~m}$ in height. During the digging of a gallery of a foggara, wells are drilled perpendicular to the gallery, and play no part in the catchment. Their function is the evacuation of the cuttings during the first phase (digging) and cleaning of the gallery during the second phase (exploitation of foggara). From satellite images and aerial photos, the alignment of the wells is easily spotted. The openings of the wells are surrounded by rubble from the excavation and cleaning of galleries. The diameter of the well is not constant, it varies from $0.5 \mathrm{~m}$ to $1.2 \mathrm{~m}$. Their depth varies between 2 and $60 \mathrm{~m}$. The deepest are located in, draining part to reach the water table. The number of wells drilled in foggara between 4 and 2000. Some the foggaras in the Touat come with sand traps; it is small settling ponds that allow sand particles to settle before reaching the Kasria.

The gallery of a foggara is divided into two parts: the first located at the upstream which is at most $2 / 3$ of the total length of a gallery. It is located below the hydraulic grade line and the interior of the web. This is the most important part of the foggara which is intended for the collection of the water of the water table. The lifespan of a foggara is linked to the drainage gallery. The flow of a foggara is a function of the length of the draining gallery, which is considered the true pump from the foggara. In this part, the wet section is usually full. The length of the drainage portion is variable over time for a water table due to the variation in rainfall [REMINI et al. 2010]. During the wet season, the drainage gallery is maximum since the table is resupplied by rainwater. In this case, the inactive portion becomes lower. By cons, during the dry season, the drainage gallery is at a minimum and the transportation portion becomes aunt (Fig. 5). However for the foggaras of the Touat and Gourara draining the waters of the immense sheet of Intercalary Continental, the drainage gallery remains stationary during the years since the tablecloth Albian is not renewable whose design capacity is around 60 trillion $\mathrm{m}^{3}$ [CASTANY 1982; DOB 2003; GUIDO 2005]. However the contribution of new techniques such as the installation of deep wells in the Sahara contributed much to the drawdown. Unlike foggara that captures water from an aquifer which the drainage gallery may decrease or increase several times during the year, the drainage gallery of a foggara of the Touat and Gourara slowly decreasing for years. The second part called transport is downstream and is $1 / 3$ of the total length of the gallery may be intended to carry drainage water to the soil surface (Fig. 4f). On thirty the foggaras which we visited and the information gathered from the Ksourienne population, we obtained that the drainage portion does not exceed $2 / 3$ of the total gallery. The transport component is around $1 / 3$ of the total gallery. However, in the technical literature, it is suggested that the draining part does not exceed $1 / 2$ of the total gallery. Other authors argue that the drainage portion is equal to the total of the gallery foggara. This case is unique and it is very rare to meet a foggara is draining its entire length. A foggara which the initial flow rate has not undergone change, the draining gallery can
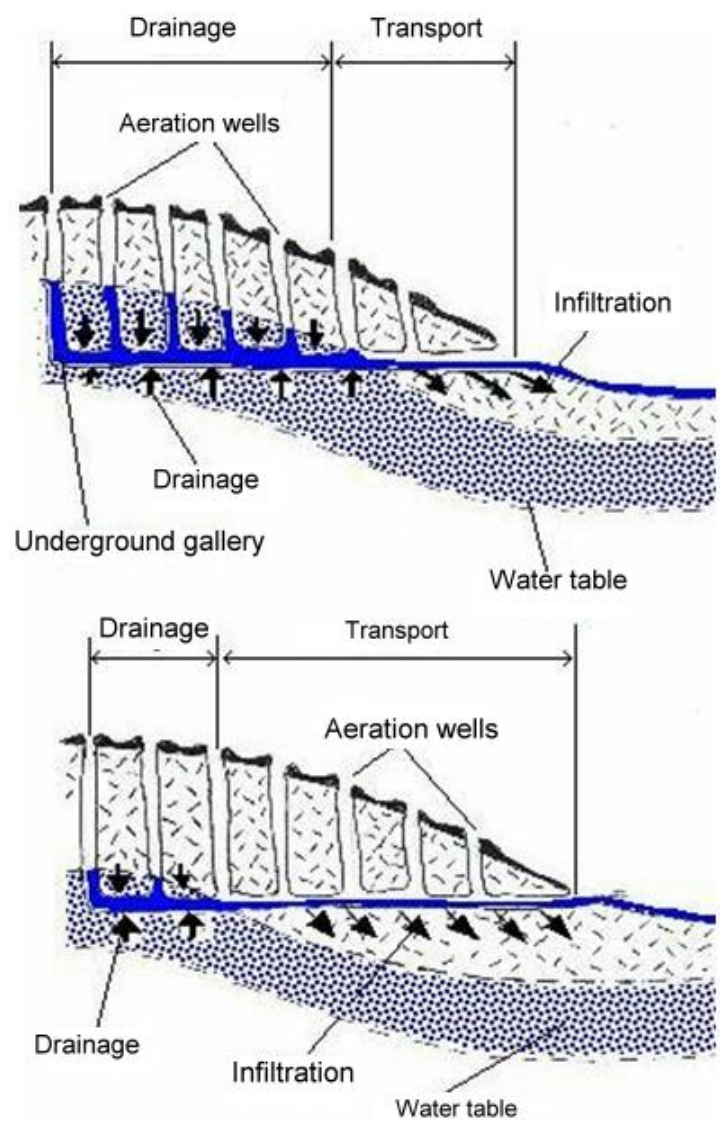

Fig. 5. Schematic of active and inactive parts of a gallery; source: own elaboration 
vary from $1 / 2$ to $2 / 3$ of the total length of the gallery. The scheme of figure 6 illustrates the regression of the drainage portion. Indeed, after the completion of the excavation and the commissioning of a foggara of the Touat and Gourara, the hydraulic grade line down (drawdown) from its initial position and localizes to the new position. In this case, the hydraulic grade line intersects the gallery at a point $\mathrm{M}$, forming a drainage gallery and a transport gallery. The point $\mathrm{M}$ is the real indicator of the "health" of the foggara. Stationarity of the point $\mathrm{M}$ explains the stationarity of the discharge from the foggaras and therefore the flow will remain in the permanent foggara. During operation of the foggara, the point $M$ moves upstream (towards the mother well), the discharge of the foggara decreases.

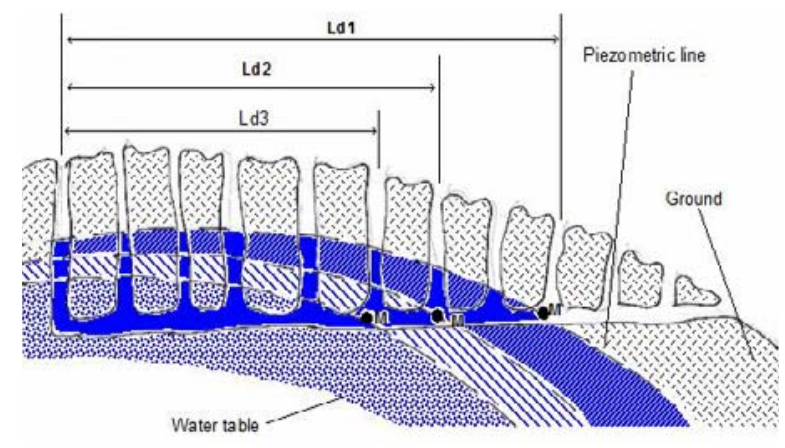

Fig. 6. Change in the drainage gallery; source: own elaboration

\section{THE DISCHARGE OF A FOGGARA}

In the draining part of the gallery of a foggara (active part), subsurface flows are external to the gallery. In the transport section, the flows are of the gallery to the outside. Therefore, in the transport part of the gallery (inactive portion), a portion of drained water (which comes from the draining part) infiltrates before reaching the ground surface (Fig. 7).

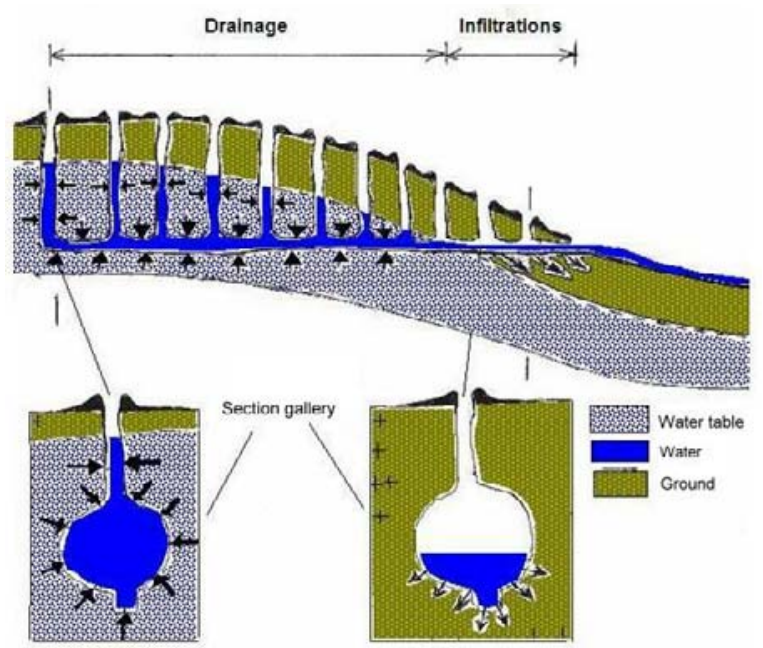

Fig. 7. Operation of the gallery of a foggara; source: own elaboration
The discharge of the foggara is the flow rate measured at the output of the gallery and may writes:

$$
Q f=Q d-Q I
$$

$Q f=$ discharge of the foggara,

$Q d=$ discharge of drainage,

$Q I=$ discharge of infiltration.

The drainage flow rate of depends on the length of drainage and soil permeability.

Is $Q f=f(L d, k)$

$L d=$ length of the drainage part,

$K=$ Darcy's permeability coefficient.

The flow rate of infiltration is dependent on the length of infiltration and soil permeability.

Is $Q I=f(L I, k)$.

The more the length of the draining portion increases (and automatically the length of the carrying part decreases), the greater the flow from the foggaras increases and otherwise, the flow from the foggaras decreases. The water collected by the active part flows into the inactive part before reaching the exit, a significant percentage of that water seeps into the ground. Plus the length of the inactive gallery, the greater the flow rate lost by infiltration $(I Q)$ becomes important. Infiltration in the transport part were estimated from 10 to $20 \%$ of the total flow drained [National Agency of Water Resources 1983]. The drying up of a foggara can be fast as we imagine it will take place when the drainage flow becomes equal to the infiltration rate $(Q d=I Q)$. A decrease in the drainage length $(L d)$ will cause a decrease in drainage rate and an increase in the leakage flow due to the increase of the transport length $(L t)$. There is a drainage length limit $L d i$ from which the equal drainage flow infiltration flow $(Q d=I Q)$ or the discharge of the foggara $(Q f=0)$. The throughput of a foggara increases from 0 matching $L d l$ to the maximum value which corresponds to $L d=2 / 3 L$. It decreases according to the length of conveyance of the maximum value corresponding to $L t=1 / 3 L$ to 0 which corresponds to the limit value $L t l(Q d=Q i)$ (Fig. 8).

Using inventory data for the foggaras of Gourara and the Touat conducted in 1932 and 1960 by the National Agency of water resources, we have shown in Figures 9a, b and 10a, b, relationships: flow rate according to the length of the gallery. It is interesting that the throughput of a foggara changes linearly depending on the length of the gallery to the inventory data of 1932. For cons, it is virtually impossible to connect the flow rate and length of the gallery on the inventory data 1998 (Fig. 11a, b). This is due to regression of the flow in several the foggaras because of the absence of maintenance and cleaning galleries. The contribution of modern harvesting technologies since the sixties caused the drawdown and therefore 

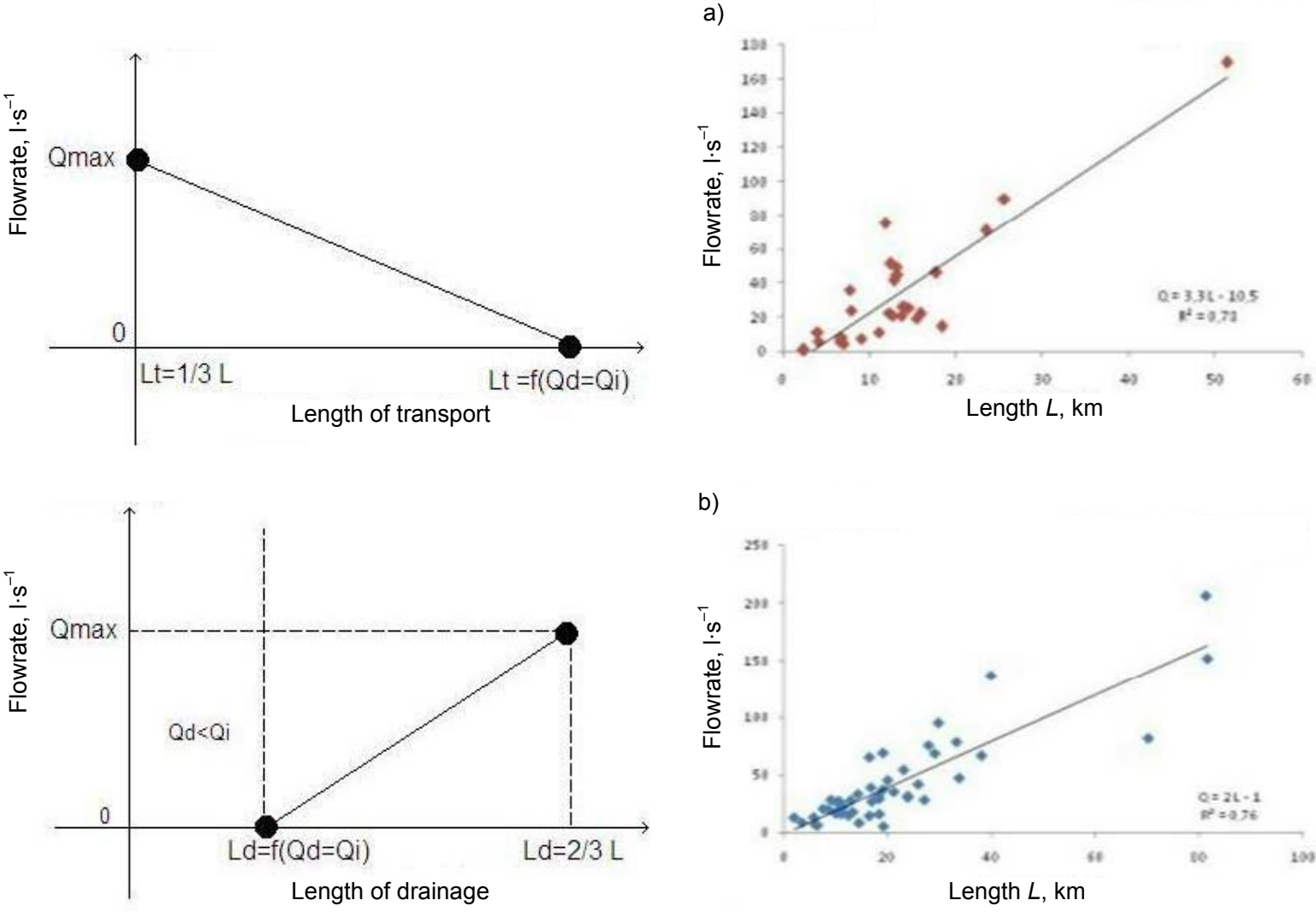

Fig. 8. Evolution of the throughput of a foggara depending the length of transport and drainage; source: own elaboration

a)

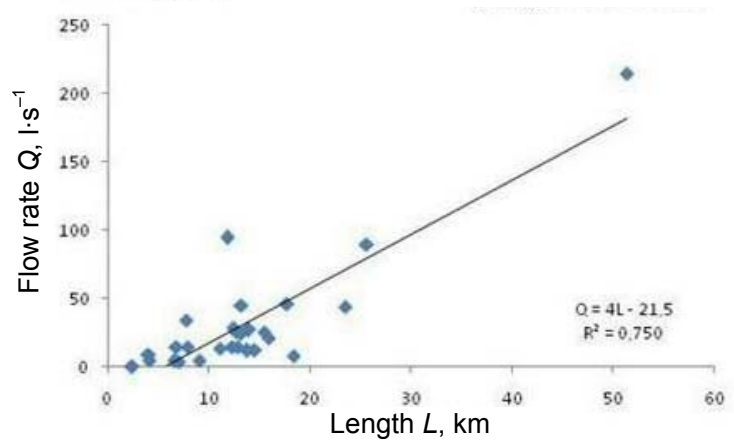

b)

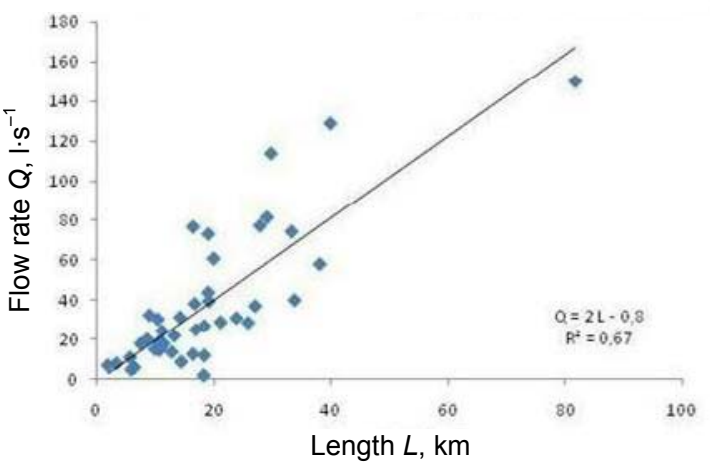

Fig. 9. Relationship between the flow rate and the length of a foggara Inventory (1932); a) foggaras of Gourara,

b) foggaras of Touat 1932; source: own elaboration based on data Arrus, 1982

Fig. 10. Relationship between the flow rate and the length of a foggara Inventory (1960); a) foggaras of Gourara 1960, b) foggaras of Touat 1960; source: own elaboration based on data Arrus, 1982

a)

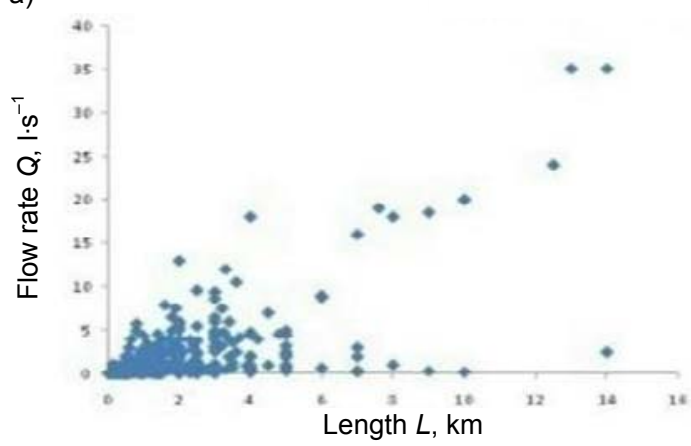

b)

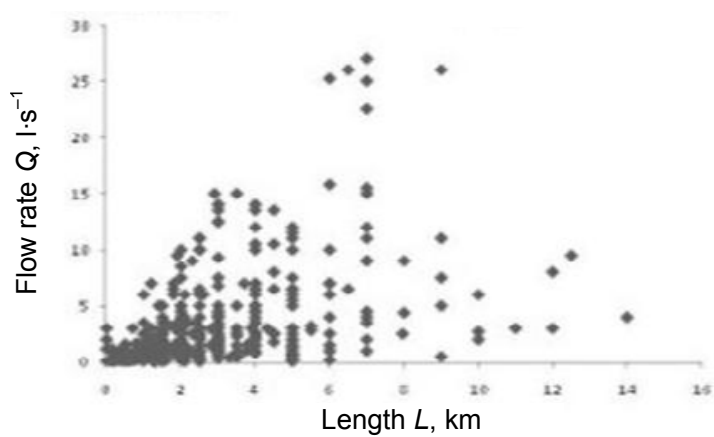

Fig. 11. Relationship between the flow rate and the length of a foggara Inventory (1998); a) foggaras of Gourara 1998,

b) foggaras of Touat 1998; source: own elaboration based on data of National Agency for Water Resources 
decreasing the flow rate of foggaras. Figure 12 represents the flow rate depending on the length of the galleries of some of the world's countries qanats confirms this linear evolution.

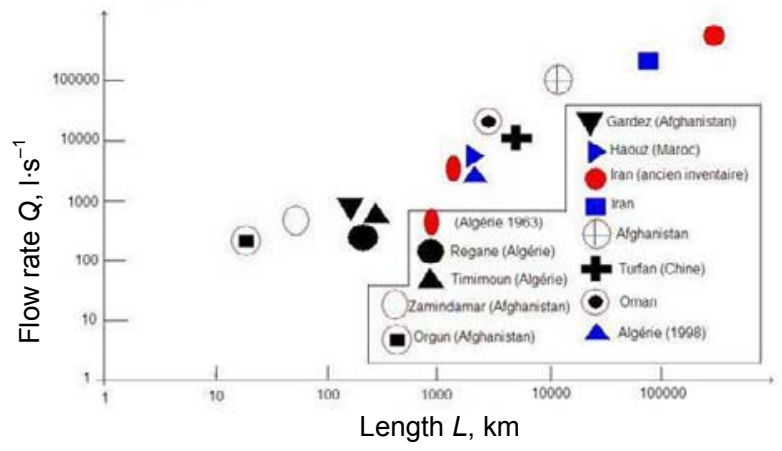

Fig. 12. Evolution of the throughput of a foggara depending on the length; source: own elaboration

\section{DIGGING THE DIFFICULTIES OF FOGGARA}

Digging a foggara takes place from downstream to upstream. Until today, no one can explain how the digging was done in the drainage part. Indeed, the digging begins in the inactive portion where the soil is dry. The digging is done with rudimentary material means digging the first sections of the gallery and the first wells to evacuate cuttings and so to oxygenate the basement. But the arrival of the active part, the soil is saturated with water and the work becomes more difficult. The mud evacuation poses enormous problems for diggers. Landslides are increasing more and more as the digging of the gallery advance. If the work in the inactive portion progressing well in the drainage part, the excavation work slow because of the water.

\section{COLLAPSE OF A FOGGARA}

Frequent landslides took place in the gallery of a foggara. Maintenance operations and maintenance are performed routinely pat the ksouriens. Small landslides are common in a foggara and cause narrowing of the wet section and therefore a reduction in the flow from the foggaras. The sharp reduction in the flow of a foggara may be due to a strong landslide in the transportation part resulting in clogging of the gallery. In this case, the leakage increase and all wells are filled with water. The cleaning becomes more complicated and makes the difficult task for ksouriens (Fig. 13).

\section{HOW TO INCREASE THE THROUGHPUT OF A FOGGARA}

Since the forties, there is a decreased flow of the foggaras in the Touat and Gourara following drawdown caused by the contribution of new water harvesting techniques. Various technical proposals can improve throughput of foggaras.

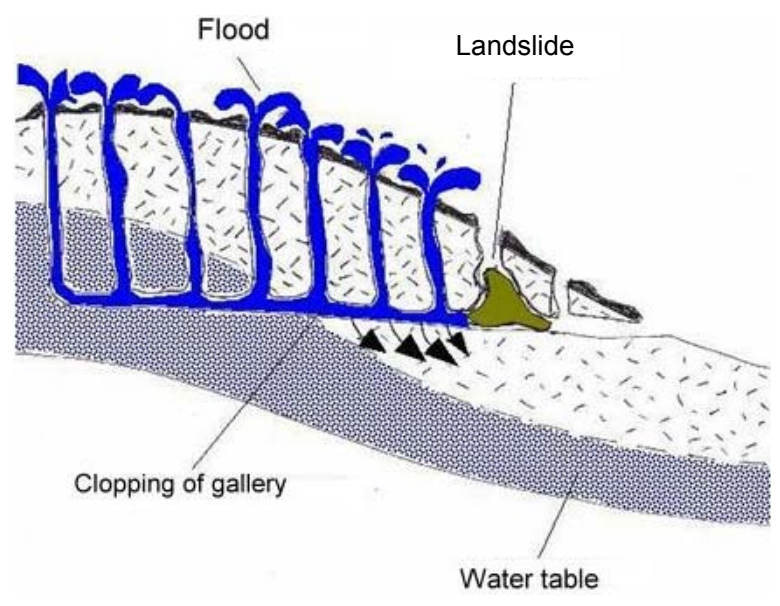

Fig. 13. Simplified schematic of a process in a collapse of foggara; source: own elaboration

- The ksouriens use for centuries the extension of the drainage gallery upstream. This technique is called Tarha (Fig. 14) [REMINI et al. 2012a]. In this part the well becomes deeper in order to reach the web. Well depth often exceeds $40 \mathrm{~m}$.

- To retrieve the flow rate infiltrated the inactive part, the ksouriens dug a small foggara downstream of the initial foggara which aims to capture the seepage water (Fig. 15). This technique has been used in a few oasis of Timimoun.

- Wells to balance or animal attraction has been made in the gardens of some oasis that can recover water infiltration foggaras (Fig. 16).

- A solution that can minimize seepage to the inactive portion and thereby increase the flow of foggara. It involves the construction of the channel of the transport part. The better the conductivity pro-

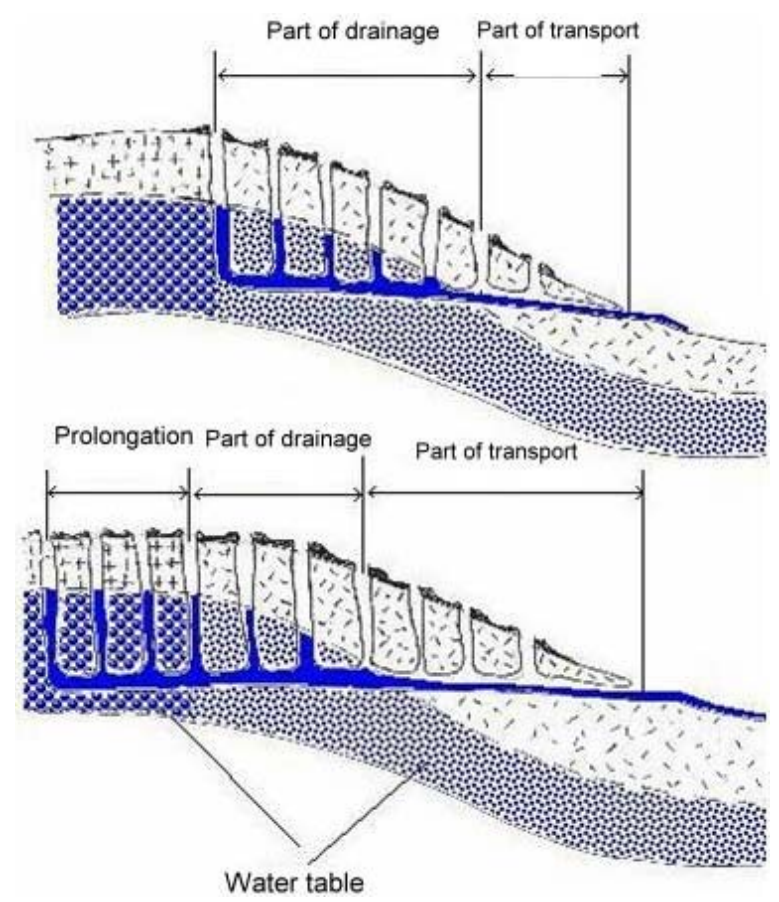

Fig. 14. Diagram of an extension to the gallery; source: own elaboration 


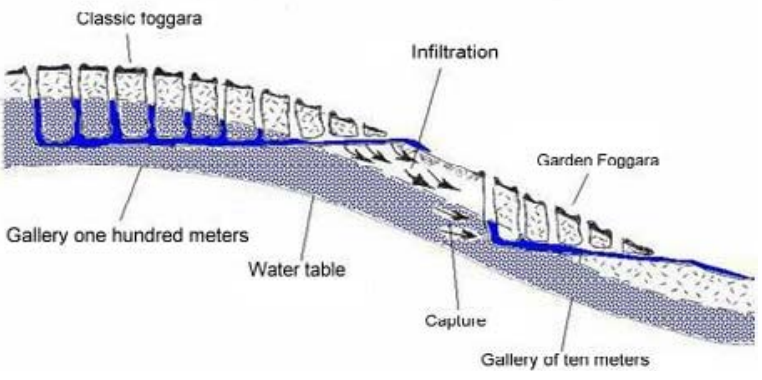

Fig. 15. Diagram of the operation of a small foggara located downstream of ancient of foggara; source: own elaboration

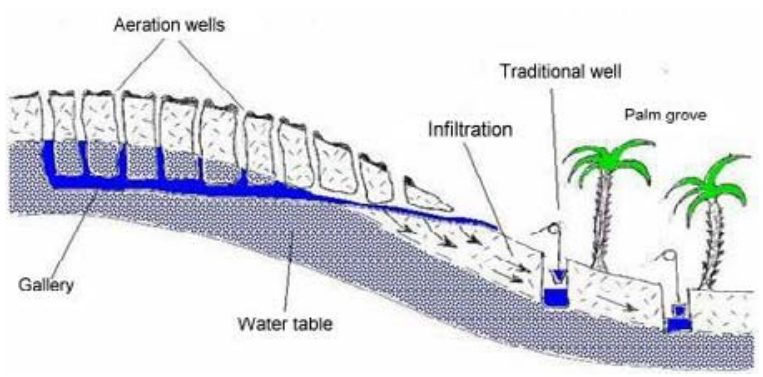

Fig. 16. Schematic of recharge of wells by infiltration originating from a foggara; source: own elaboration

file can be in this case a half circular section made of cement. Will there be virtually zero infiltration rates and a low coefficient of Manning Strikler, which can increase the discharge of the foggara becomes equal to the flow rate of drainage.

\section{CONCLUSIONS}

As we mentioned earlier in this article, the foggara is one of the most sustainable techniques in the history of hydraulic since remained in operation more than 10 centuries. Over 1400 foggaras were dug in the Algerian Sahara. Several types of foggaras were developed as the source foggara, the flood foggara, the Erg foggara, the Albian foggara and the Wadi foggara. Today there are less than 600 foggaras in operation but with a low rate that does not exceed $3 \mathrm{~m}^{3} \cdot \mathrm{s}^{-1}$. The foggara has faced for over a half-century of the sheet folding problem.

The expansion of palm groves, the development of oasis and bringing new sensing techniques has influenced the reduced flow foggaras of Touat and Gourara. Despite these constraints, foggaras continued to function through the application of flow improvement techniques and the reduction of infiltration. We can mention the extension of the drainage gallery at the upstream of the mother well, Achieving small foggaras downstream large foggaras, digging wells animal traction or balance in the downstream part of the foggaras and development of the part of inactive gallery are the most used in the oasis of Tuat and Gourara techniques.

\section{REFERENCES}

ABIDI S., REMINI B. 2011. Les foggaras de Touat : la fierté de la population locale [The foggaras of Touat: The pride of the local population]. Annales des Sciences et Technologie (Ouargla University). Vol. 3. No. 2 p. 107113.

ARrus R. 1985. L'eau en Algérie [Water in Algeria]. Alger University Publications Office. ISBN 2-7061-0260-8 pp. 388

Castany G. 1982. Principes et méthodes de l'hydrogéologie [Principles and practices of hydrogeology]. Paris. Dunod University pp. 238.

Doв M.E. 2003. Use of Albian: advantages and disadvantages. Collected papers of scientific and technical days on the water quality of the South. Proceeding of seminar. Vol. 1. El Oued University (Algeria) on 20 and 21 May pp. 79.

Guido M. 2005. Well design pressure in the Continental Intercalary. Proceeding of the international symposium on groundwater resources of the Sahara - CIRESS. Ouargla, 12 and 13 December pp. 194.

Goblot H. 1979. Les qanats une technique d'acquisition de l'eau [Qanats: a technique for acquiring water]. Paris. Mouton. ISBN 2-7193-0459-X pp. 231.

HofmAN A. 2007. La gestion traditionnelle de l'eau par qanat en Iran est-elle compatible avec le concept de la GIRE? [The traditional management of water qanat in Iran is compatible with the concept of IWRM]. Synthesis technique. Montpellier. ENGREF pp. 17.

LIGHTFOOT D.R. 1996. Moroccan khettara: traditional irrigation and progressive desiccation. Geoforum. Vol. 27. No. 2 p. 261-273.

National Agency for Water Resources 1986. Foggaras of Touat and Gourara. Study of the operation and improvement opportunities. Technical manual pp. 50.

REMini B., ACHOUR B. 2008. Vers la disparition de l'une des plus grandes foggaras d'Algérie: la foggara d'El Meghier [Towards the disappearance of one of the largest foggaras of Algeria: The foggara of El Meghier]. Sécheresse. Vol. 19. Iss. 3 p. 217-221.

Remini B., ACHOUR B. 2013a. Foggaras of Ahaggar: Disappearance of a hydraulic heritage. Larhyss Journal. No. 14 p. $149-159$.

Remini B., Achour B. 2013b. The foggaras of In Salah (Algeria): The forgotten heritage. Larhyss Journal. No. 15 p. 85-95.

Remini B., ACHOUR B. 2013c. The triple foggara of Ouled Said (Algeria): The ingenuity of the Saharan peasantry. Larhyss Journal. No. 15 p. 113-122.

Remini B., Achour B., Albergel J. 2011. Timimoun's foggara (Algeria): An heritage in danger. Arabian Journal of Geosciences. Vol. 4. No. 3. DOI 10.1007/ s12517-010-0139-9 p. 495-506.

Remini B., Achour B., Kechad R. 2010. Les types de foggaras en Algérie [The types of foggara in Algeria]. Revue Sciences de l'eau (Canada-France). Vol. 23. No. 2 p. 105-117.

Remini B., Achour B., Kechad R. 2012a. Traditional techniques for increasing the discharge fromqanats in Algeria. Irrigation and Drainage Systems. Vol. 25. No. 4 p. 293-306. DOI: 10.1007/S10795-012-9125-6.

REMini B., ACHOUR B., KeCHAD R. 2014a. The collecting of groundwater by the qanats: A millennium technique decaying. Larhyss Journal. No. 20 p. 259-277. 
Remini B., Achour B., Oouled Belkhir C., BabA Amar D. 2012b. The Mzab foggara: An original technique for collecting the water rising. Journal of Water and Land Development. No. 16 p. 49-53.

Remini B., Rezoug C., Achour B. 2014b. The foggara of Kenadsa (Algeria). Larhyss Journal. No. 18 p. 93-105.
Rezzoug C., Remini B., Hamoudi S. 2016. L'irrigation moderne dans l'oasis Lahmar (Bechar, Algerie): Problematique et consequences [Modern irrigation in the oasis Lahmar (Bechar, Algeria): Problems and consequences]. Larhyss Journal. No. 25 p. 259-267.

\section{Boualem REMINI}

\section{Rola galerii w funkcjonowaniu foggary (podziemnej instalacji wodnej)}

\section{STRESZCZENIE}

Slowa kluczowe: galeria, Gourara, przeptyw, Touat, woda

$\mathrm{W}$ przedstawionej pracy objaśniamy rolę galerii $\mathrm{w}$ usprawnianiu przepływu wody $\mathrm{w}$ foggarze. Badania oparto na obserwacjach i ostatnim spisie z roku 1998. Galeria foggary składa się z dwóch części: odwadniającej i transportowej. Część odwadniająca jest zlokalizowana w poziomie wodonośnym i stanowi $2 / 3$ galerii. Część transportowa ma długość $1 / 3$ galerii. Znając zasady działania podziemnej instalacji wodnej zaproponowano dawne metody usprawnienia przepływu w podziemnym kanale. Obejmują one rozszerzenie drenującej części galerii, wzmocnienie i uszczelnienie transportowej części galerii, zbudowanie małego kanału i kopanie studni poniżej głównej instalacji. 